
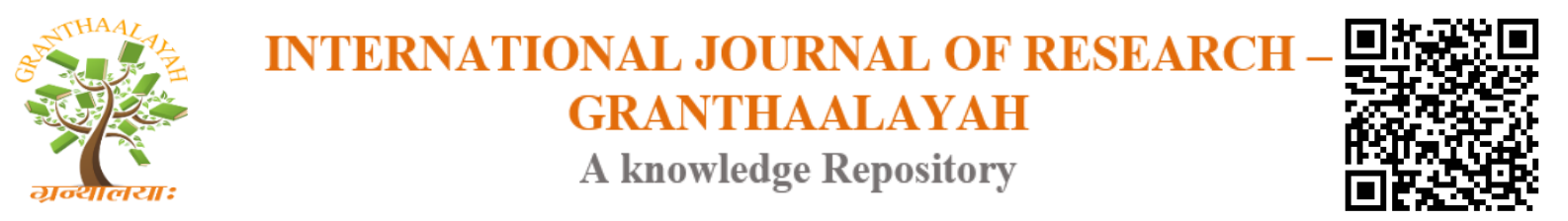

Science

\title{
DELINEATION OF GEOMETRY AND SPATIAL DISTRIBUTION OF BASIC BODIES USING MAGNETIC AND RESISTIVITY METHODS IN SOHAGPUR COAL FIELD AREA, MADHYA PRADESH
}

\author{
D.C. Naskar ${ }^{* 1}$, M.K. Rai ${ }^{2}$ \\ ${ }^{*}$ Geophysics Division, Geological Survey of India, Southern Region, Hyderabad-500068, India \\ ${ }^{2}$ Geophysics Division, Geological Survey of India, RSAS, Bengaluru-500078, India
}

\begin{abstract}
The state of Madhya Pradesh in Central India is known to bear 'A' grade coal seams within Gondwana basin. An alluvium-covered area to the north-east of Shahdol was considered to be prospective for the exploration of coal. A number of basic intrusive are encountered in the area and these appear to have played an important role for enhancement of the rank of coal seams. Delineation of the geometry and spatial distribution of these basic bodies has therefore become necessary for exploration of high rank coal seams. Magnetic and resistivity surveys were mainly carried out. Geologically, the alluvium covered area was known to be composed of rocks of different ages such as Precambrian, Gondwana Triassic, Cretaceous (trap) and older alluvium in succession. Gondwana basins are formed over basement depressions or in the downthrown side of the faulted Precambrian. Gondwana sediments lying over such basement sub-basins are prospective areas for the exploration of coal. The magnetic map was vitiated through the presence of high amplitude and small wavelength anomalies due to a thick blanket of basic bodies lying above the Gondwana sediments. Fluctuations in magnetic responses are observed at a few locations which may be due to the presence of basement faults? Low intensity but distinct anomaly patterns are observed in the south-western part of the area possibly indicating subsurface basic intrusive. 2D modeling of the magnetic data has effectively brought out the basement depth varying between $680 \mathrm{~m}$ to $1460 \mathrm{~m}$ an increasing trend from west to east. Selected resistivity soundings confirm that the overlying high resistivity layer (107-390 Ohm-m) and of thickness $(0.7-386.3 \mathrm{~m})$ may possibly indicate the geometry of basic bodies from the surface to depth of $547.5 \mathrm{~m}$. The basement could not be picked up.
\end{abstract}

Keywords: MP; Sohagpur; Shahdol; Gondwana; Magnetic \& Resistivity Methods; 2d Model.

Cite This Article: D.C. Naskar, and M.K. Rai (2018). "DELINEATION OF GEOMETRY AND SPATIAL DISTRIBUTION OF BASIC BODIES USING MAGNETIC AND RESISTIVITY METHODS IN SOHAGPUR COAL FIELD AREA, MADHYA PRADESH." International Journal of Research - Granthaalayah, 6(8), 146-158. 10.29121/granthaalayah.v6.i8.2018.1408. 


\section{Introduction}

The Gondwana sediments have been deposited in several known paleo-channels (faulted basins) over the Precambrian rocks in India. These sediments are known to be coal-bearing and coal being mined from these basins in the states of West Bengal, Bihar, Madhya Pradesh and Maharashtra. A large lava flow of basalt covered the Gondwana and Triassic sediments during the Cretaceous period which is known as the Deccan trap. Subsequently, Tertiary rocks and older alluvium covered this flow at many places. The area was then subjected to tectonic disturbances which resulted in the formation of faulted basins. The Sohagpur coal field area covered by this survey falls within such a region on the western part of Rewa basin (Figure 1). The Sohagpur coal field extends over a length of about $103 \mathrm{~km}$ in E-W direction with width of about $43 \mathrm{~km}$ in the N-S direction in the Shahdol district of Madhya Pradesh (MP).

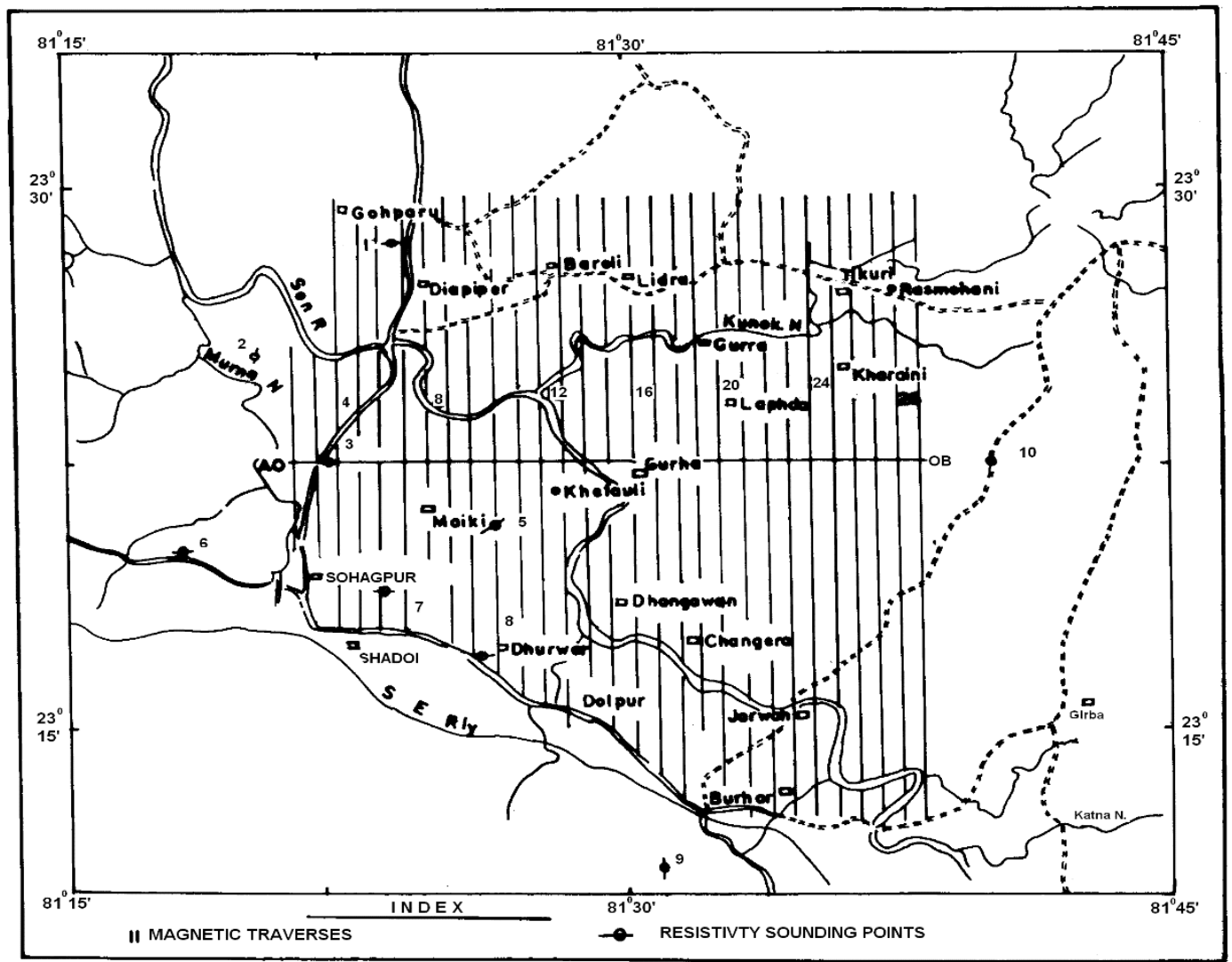

Figure 1: Lay out map showing magnetic traverses and resistivity sounding locations in Sohagpur coal field, district Shahdol, Madhya Pradesh.

The Bouguer gravity map of the Sohagpur area indicates an undulating nature (a number of lows and highs) of the basement topography (Joga Rao et al. 1984) which is covered by a variable thickness of lower Gondwana sediments. Most of these lows lie along the central part of the Sohagpur coal field, north of Bamhani-Chilpa fault. The high appears to be due to compounding effects of subsurface intrusive and shallow basement rocks.

The area of high rank coal is mainly bounded between the Bamhani-Chilpa fault to the south and the Pali to the north. A lot of geological studies have been carried out which showed that there is 
a change in coal seams development on either side of the Bamhani-Chilpa fault. Since the occurrence of basic intrusive (low angle dykes) appear to have played an important role for enhancement of rank of the coal seams (Venkatappyya et al. 1968), it was felt necessary to have an idea about the geometry and spatial distributions of these basic bodies with the help of geophysical surveys by magnetic and limited resistivity methods.

\section{Geology}

Sohagpur coal field is a part of large sediment filled Rewa Gondwana basin within the drainage area of Son River (Ghosh et al. 1996). The Precambrian basement rocks are not exposed in the vicinity of the coal field, which crop out as inliers within the Talchir formation in other areas. The Talchir strata are found to the south of the coal field and continue beneath the coal measures. The overlying Barakar formation contains the regionally distributed economic coal beds of Sohagpur coal field. Barren measures (sandstone and siltstone, a chloritic matrix) strata are overlain by Raniganj beds. Raniganj coals are associated with interlaminated and rippled fine grained sandstone and shale. Raniganj strata are, in turn, overlain by Late Permian and Early Triassic Pali rocks which are represented by a sequence of very coarse grained to pebbly sub-arkosic to arkosic sandstones, interspersed with thin shale bands. Lameta strata occur along the fringes of trap covered hills in the south-west part of Sohagpur coal field. They rest unconformable over the Gondwana strata (Figure 2).

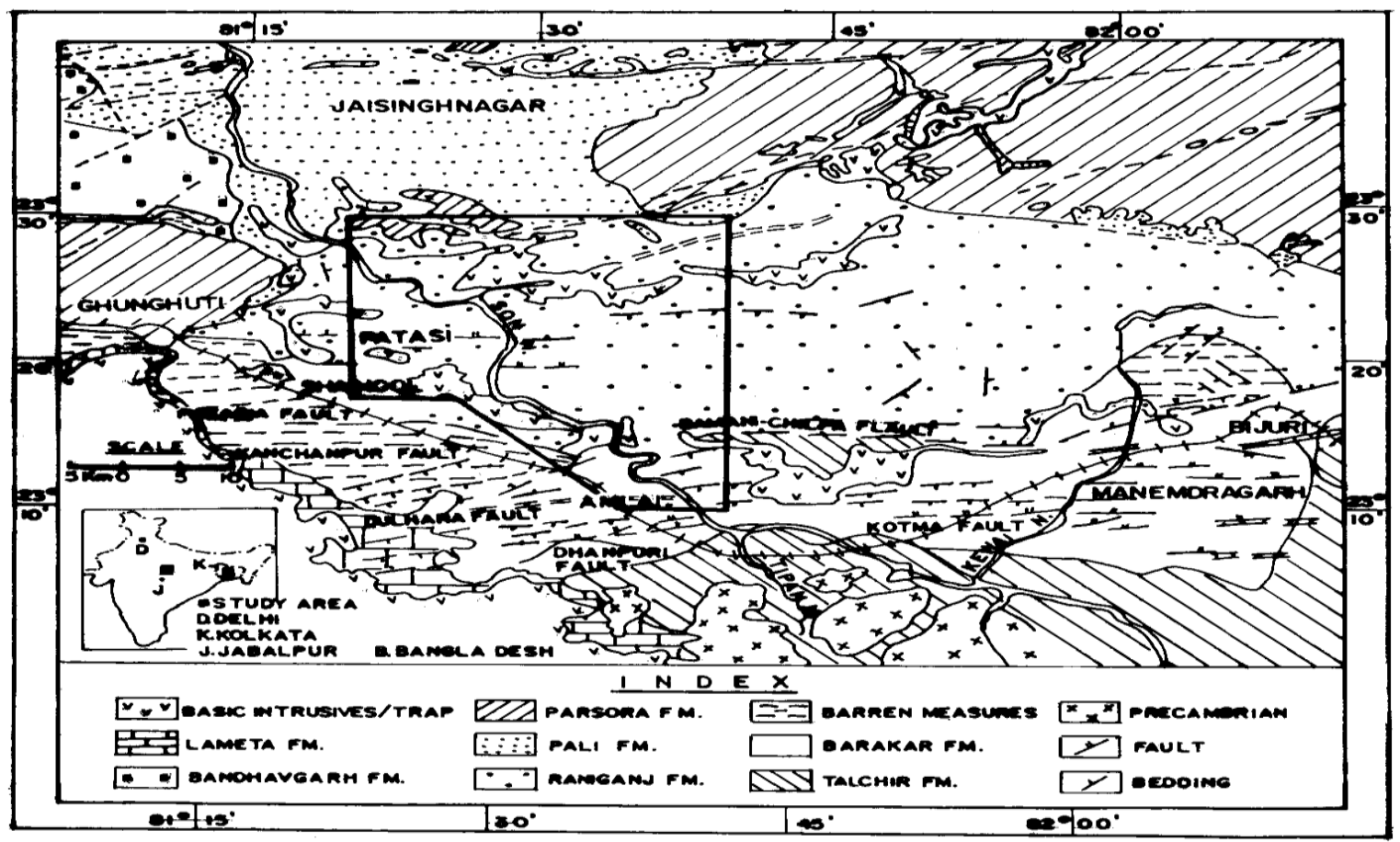

Figure 2: Geological map of Sohagpur coal field, Madhya Pradesh.

Gondwana strata are traversed by a large number of basic dykes and sills. Extraneous heat source from the igneous bodies probably attributed to the rank enhancement of the coal seams. The geological formation in the area, their sequence, nature of occurrence in the coal field is given below: 
[Naskar et. al., Vol.6 (Iss.8): August 2018]

(Received: July 14, 2018 - Accepted: August 21, 2018)

Name of formation

Alluvium/soil

Sills, dykes and flows of Deccan trap

Lameta beds

Pali formation

Permian

Raniganj formation

Barren measures

Barakar formation

Talchir formation
Thickness

0-30

60-100
ISSN- 2350-0530(O), ISSN- 2394-3629(P)

DOI: 10.5281/zenodo.1403846

Age

Recent and Sub-recent

Upper Cretaceous

Upper Cretaceous

\section{Unconformity}

600

$+500$

200-300

250-300

$+400$
Lower Triassic to upper

Upper Permian

Upper Permian

Lower Permian

Lower Permian

Unconformity

Precambrian basement

\section{Structure}

The major structural features of this area are sets of sub-parallel east-west trending strike fault which have variously affected the Gondwana sediments. The most important one of these eastwest faults have been described as the Bamhani-Chilpa fault which runs through the central part of Sohagpur coal field dividing the area into a shallow uplifted southern block and a northern down thrown segment. This fault has been conduit for intrusion of dykes and sills of Deccan trap affinity (Figure 2), a suite of iron rich continental dolerite basalt type. The coalfield underwent at least two major tectonic movements after the coalification process was completed. The first was probably of post Triassic age when the southerly dipping extensional fault came into existence. The second tectonic movement probably coincides with the effusion of Deccan trap, when most of the major faults were re-activated.

\section{Geophysical Studies}

\section{Layout of Field Operations}

Magnetic survey was carried out employing a Scintrex make Vertical Force (VF) Fluxgate Magnetometer (MF-2, reading accuracy 1 to $10 \mathrm{nT}$ ) along N-S profile at $1 \mathrm{~km}$ interval (Figure 1) from the western part of the area. The observations were taken at $200 \mathrm{~m}$ apart along each traverse and reduced to the base station. The absolute value (VF) was $24500 \mathrm{nT}$ observed at base station. The base of magnetic profiles and zero contours in magnetic contour map corresponds to this value. The observed magnetic data have been corrected for diurnal and normal corrections. All observations have been taken with $\mathrm{N}-\mathrm{S}$ orientations and as such heading error was negligible.

A Scintrex TSQ-3 time domain resistivity unit with digital stack readout was used for field surveys. The grounded or the current sending electrodes were made of steel stakes buried in soil pits. RDC10 receiver of Scintrex make has been used for measuring the potential difference between two non-polarisable electrodes (copper dipped in saturated copper sulphate solution). The deep resistivity soundings were taken at suitable locations in an attempt to determine depths to the basement rock and to obtain depths, character and thicknesses of the different layers overlying the basement. 


\section{Magnetic Survey}

The magnetic (VF) data were plotted along 29 traverses (Figure 3) show distinct geological correlation. Lithological boundaries are clearly reflected. Raniganj formation reveals low amplitude (100 $\mathrm{nT}$ to $500 \mathrm{nT}$ ), wide ranging magnetic anomalies whereas exposed low angle basic bodies register high amplitude and small wavelength magnetic anomalies comprising "highs and lows" due to dipole nature. High amplitude anomalies are due to shallow/exposed dykes. The low amplitude anomalies observed over Raniganj formation is mostly due to disposition of basement at depth as Raniganj (sedimentary) formation is of non-magnetic character. The high amplitude, small wavelength anomalies observed in the southern as well as northern part of the surveyed area are directly over basic bodies which are exposed on the surface or at shallow depth (Figure 3).

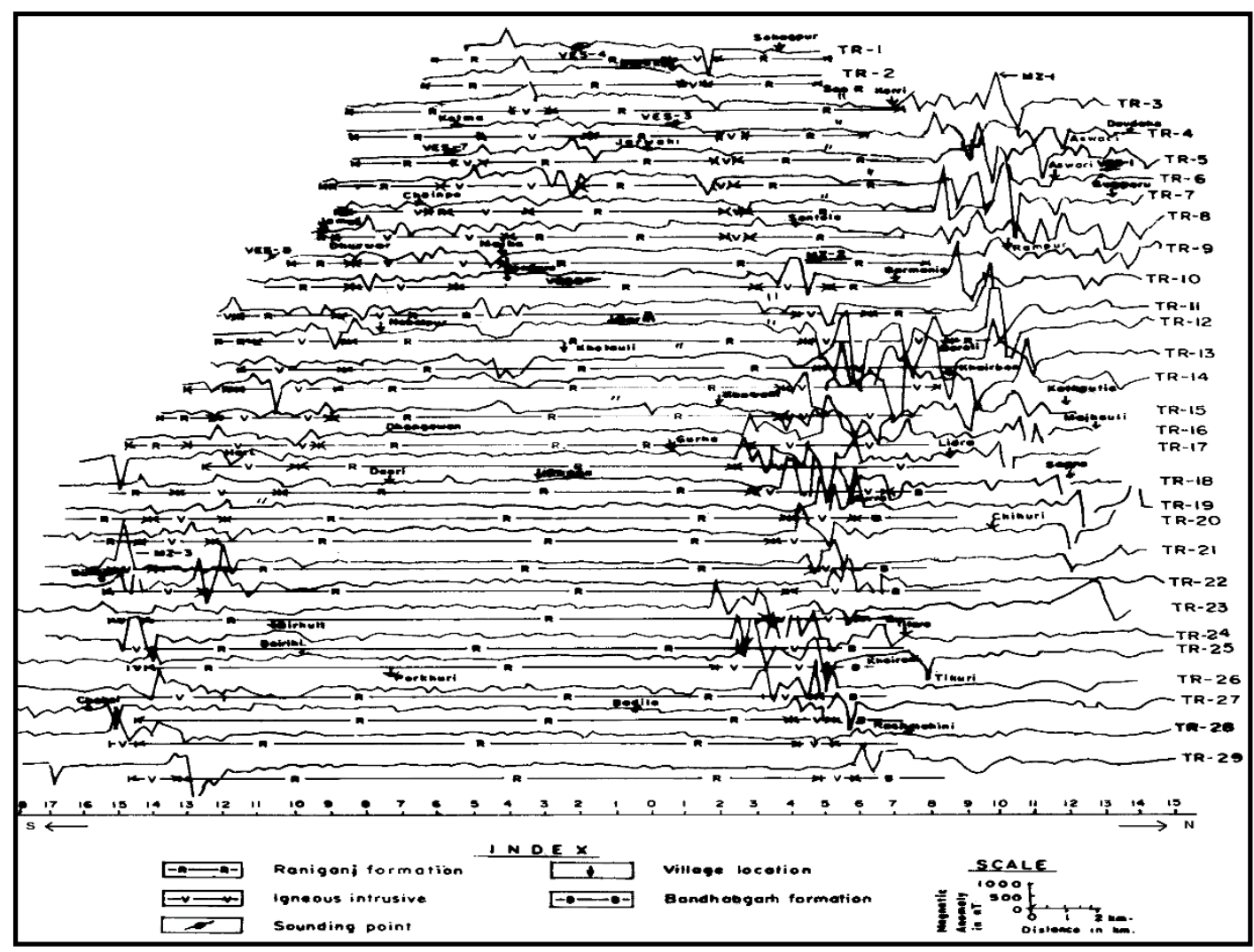

Figure 3: Magnetic (VF) anomaly along north-south traverses with geology.

Based on the amplitude and anomaly pattern, the area surveyed is demarcated in to three major anomaly zones viz. MZ-1, MZ-2 and MZ-3 which possibly reflect the lateral disposition of basic bodies, roughly in the east-west direction.

\section{Anomaly Zone, MZ-1}

This anomaly zone (Figure 3) is observed in the northern part of the area along Trav-3, north of Karri village, having width, $2.5-3 \mathrm{~km}$ and continues eastward and reflected along all the traverses passing through south of village Devdaha, Aswari, north of Barmania, Bareli, south of Kathautia and Majhauli upto the north-east of Chihuri (Trav-23). Northward shift in the anomaly zone is observed near village Sagra (Trav-18) and continues eastward till the north-east of Chihuri (Trav23). The width of the anomaly zone is almost same upto village Rampur (Trav-9), thereafter its 
width is roughly of the order of 1.5-2 km. Anomaly zone, MZ-1 reflects the spatial disposition of basic bodies in the northern part of the area in east-west direction having varying width.

\section{Anomaly Zone, MZ-2}

This magnetic anomaly zone is observed south of the anomaly zone MZ-1 along Trav-10, just north of Son River having width of the order of 600-700 $\mathrm{m}$ (Figure 3). This anomaly zone continues eastward roughly parallel to anomaly zone MZ-1 and passes through north of village Kanwahi, Gurha, south of village Gurra, Titare till the north of village Bodila (Trav-27). The width of the anomaly zone is found to be more along Trav-12 to Trav-17 due to the combined effect of the anomaly zone MZ-1 and MZ-2. Along Trav-18, west of village Gurra, width of the anomaly zone is roughly $2.5-3 \mathrm{~km}$ which decreases eastward tilled west of village Titare (Trav-22). Southward shift in the anomaly zone is observed along Trav-23 which continues eastward with slight northerly trend through Khairani with varying width. The decrease in the width of anomaly zone between village Gurra and west of Rashmohini is possibly due to deposition of Raniganj formation or having less width of the basic bodies in the area.

The basic bodies reflected along anomaly zone MZ-1 from western part of the area swing in the south-west direction near village Khairban, Lidra and follow the anomaly zone MZ-2 in east-west direction. The swinging of basic bodies makes the anomaly zone wider along Trav-12 to Trav-17. The disposition of basic bodies near Khairban, Lidra along south-west and follows the anomaly zone MZ-2. The sedimentary of Gondwana formation between north-east of Gurra and west of Rashmohini separated the anomaly zones near village Lidra (Trav-18).

\section{Anomaly Zone, MZ-3}

This anomaly zone is observed in the southern part of the area along Trav-21, north-east of Burhar and continues eastward through north of Burhar, Chaka till the Trav-29 (Figure 3). The width of the anomaly zone varies between $600 \mathrm{~m}$ to $1500 \mathrm{~m}$ representing the spatial disposition of basic bodies in this part of the area.

Apart from these three major anomaly zones, one broad anomaly zone of less amplitude has been observed in the southern part of the area along Trav-5, south of Jarwahi and continues eastward with southern trend and passes through Chainpa, south of Maiki, Nabalpur upto area south-east of village Hari representing the disposition of basic bodies along this zone which may be exposed or be at shallow depth.

\section{Magnetic Anomaly Map}

The vertical magnetic intensity anomalies are contoured and presented in Figure 4. The anomaly zones described in Figure 3 are clearly reflected in Figure 4. 


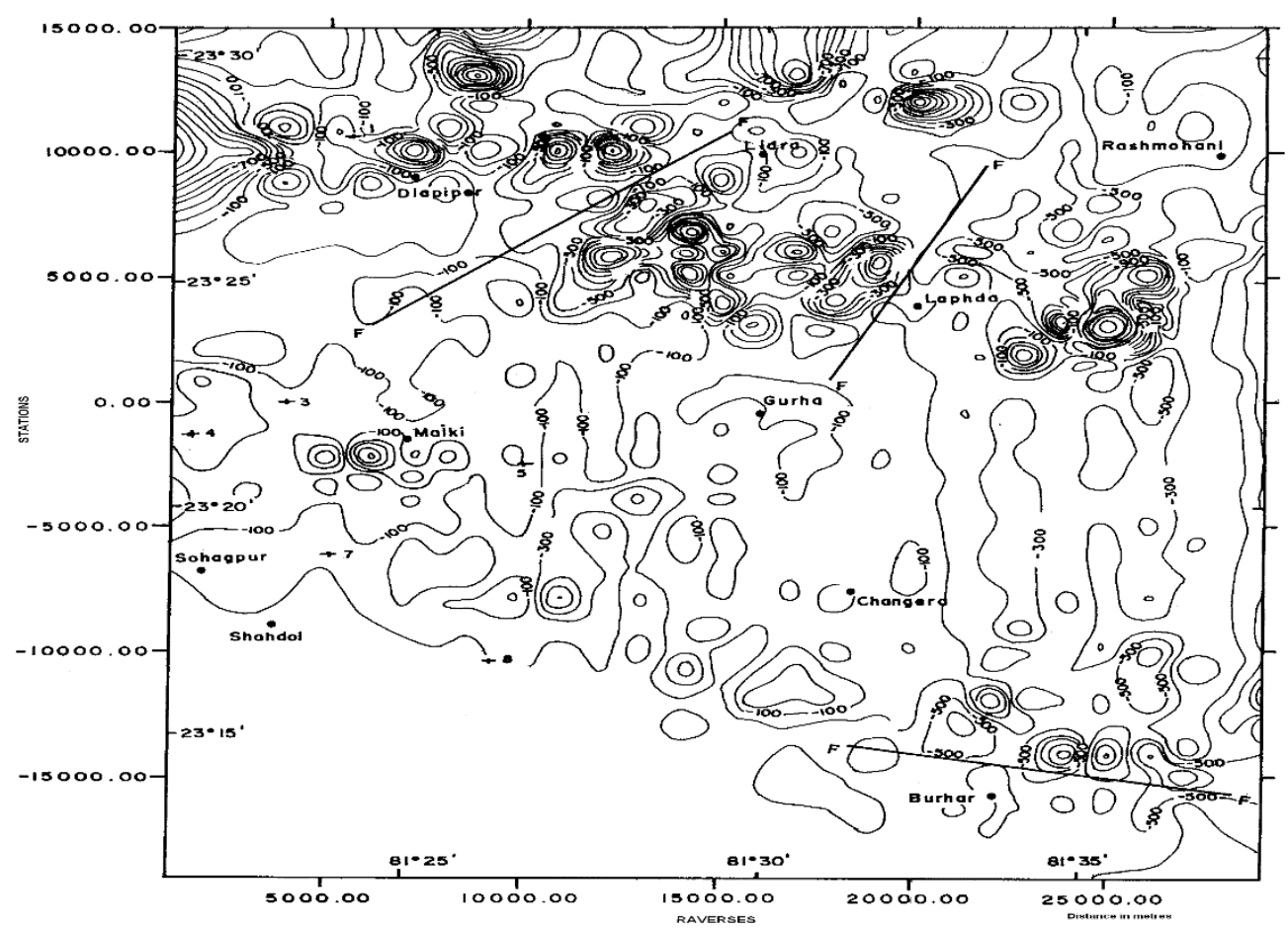

Figure 4: Magnetic (VF) contour map of Sohagpur coal field, district Shahdol, Madhya Pradesh.

The anomaly zone MZ-1 which is observed in the northern part of the area around station $10 \mathrm{~km}$ continues eastward with varying width upto the west of Lidra. The anomaly zone MZ-2, which is south-west swing of anomaly zone MZ-1, is observed along Trav-10 and continues eastward. The width of the anomaly zone is found to be more along Trav-12 to Trav-17 due to combined effect of MZ-1 and its swing towards south-west and MZ-2. Two sets of structural discontinuity (F-F and F-F) are observed magnetically in this part of the area. Anomaly zone MZ-3, observed in the southern part of the area, reveals the disposition of basic body in east-west direction north-east of Burhar. The anomalies due to the basement structure are expected to be of large wavelength and have apparently been completely overshadowed. The only redeeming feature is the general trend of the magnetic anomalies, indicating a fault zone running approximately east-west. The contours suddenly appear to be of high amplitude and small wavelength to the north-east of Burhar. This indicates that the basic body has come up upper into the upthrown side to the south. Another anomaly zone of less amplitude south-west of Maiki is also reflected in the contour map. Apart from these anomaly zones, individual high gradient closures represent localized body in the area. The observed magnetic anomaly pattern in the area mostly indicates induced magnetization.

\section{Quantitative Analysis of Magnetic (VF) Data}

Magnetic anomalies along the profile AO-OB (Figure 1) have been interpreted using a 2D magnetic modeling computer program MAG2DBAS (Murthy and Mishra, 1989) for determining the thickness of Gondwana sediments (Figure 5). One dimensional spectral analysis (Spector and Grant, 1970; Chakravorty et al. 1998) of filtered vertical magnetic field data has been carried out using MAGPROS (Rao and Ramakrishna, 1994) software and the estimated depth to the anomaly causing interface (bottom of Gondwana sediments) is shown in Figure 5. The plot shows straight line segments which decrease in slope with increasing frequency. The slopes of the segments yield estimates of average depths to the magnetic sources. The deepest part of the basin lies between Trav-15 to Trav-20 and passing through north of Dhangawan, Bhaga and north of Deori (Figure 
3). The thickness of Gondwana sediments varies between $680 \mathrm{~m}$ to $1460 \mathrm{~m}$ from west to east as depicted along the line AO-OB in Figure 5.

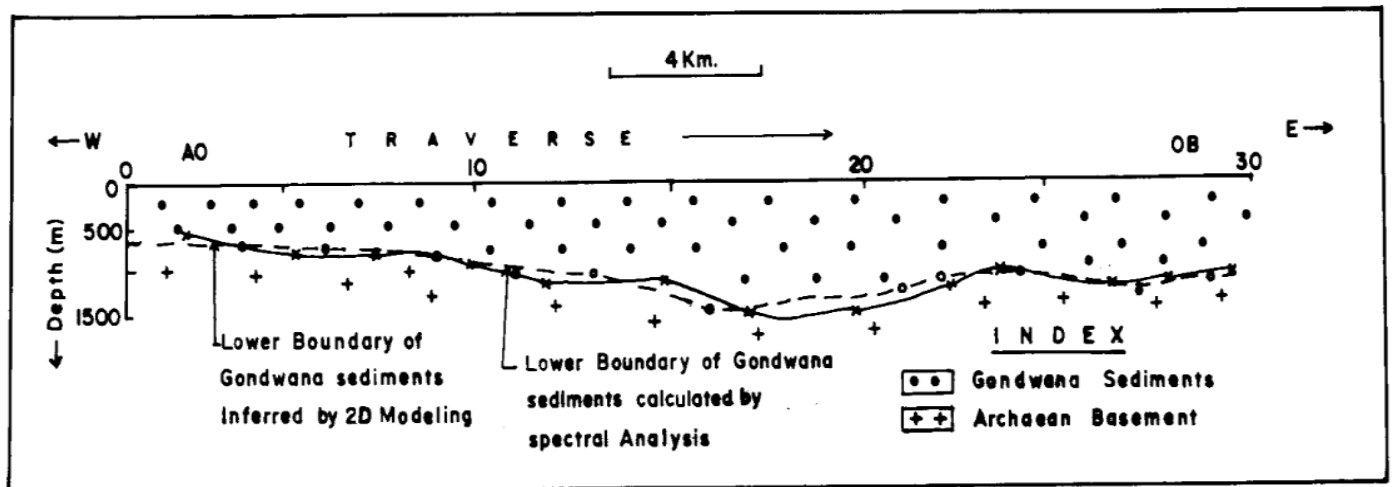

Figure 5: Magnetic (VF) profile along AO-OB. Lower boundary of Gondwana sediments inferred from 2D modeling and spectral analysis are also shown.

The interpreted thickness of Gondwana sediments from spectral analysis matches with that obtained from 2D basement mapping, based on the magnetic modeling.

\section{Deep Resistivity Sounding}

Geoelectric resistivity studies have wide applications in hydrological, structural and geothermal field investigations (Ilkisik et al. 1997; Raju and Reddy, 1998; Yadav and Abolfazli, 1998; Majumdar, 1999; Majumdar et al. 2000a; Majumdar and Paul, 2005; Majumdar et al. 2002; Stewart et al. 1983; Naskar et al. 2002; 2009). The main reason for these applications is that the overlying weathered/fractured rock or soil presents a good resistivity contrast with the compact basement crystalline rock.

In the present area of investigation, fourteen Schlumberger soundings with a maximum current electrode separation $(\mathrm{AB})$ of $2.4 \mathrm{~km}$ have been carried out. The length of the current and potential dipoles are increased keeping $\mathrm{MN}<1 / 5$ of $\mathrm{AB}$, where $\mathrm{AB}$ is current dipole length, $\mathrm{MN}$ is potential dipole length.

It may be noted that there is an overlapping resistivity range for the Deccan trap and Gondwana sediments, which makes it difficult to mark the interface between them. Demarcation of the Precambrian morphology, however, has been possible by the resistivity survey results, because of high contrast between the Deccan trap/Gondwana sediments and the Precambrian rocks. The sounding technique used is the Schlumberger system which is relatively insensitive to surficial changes in electrical properties and provides sounding curve of much better quality in heterogeneous terrain than does either the dipole or Wenner techniques (Kunetz, 1966). Resistivity sounding data are inverted for 1D model using 'Resist' technique (Vander Velpen, 1988). 1D inversion reserves its importance and utility as the interpreted model parameters can serve as starting model for 2D and 3D approaches for better approximation of the sub-surface geology of the area. In such cases, 1D interpretation is usually found to be fairly consistent with those observed in 2D and 3D inversions (Naskar et al. 2008; Majumdar et al. 2006; Naskar, 2005; Olayinka and Weller, 1997; Monteiro Santos et al. 1997; Majumdar et al. 2000b). 
Some representative sounding curves are shown in Figure 6.
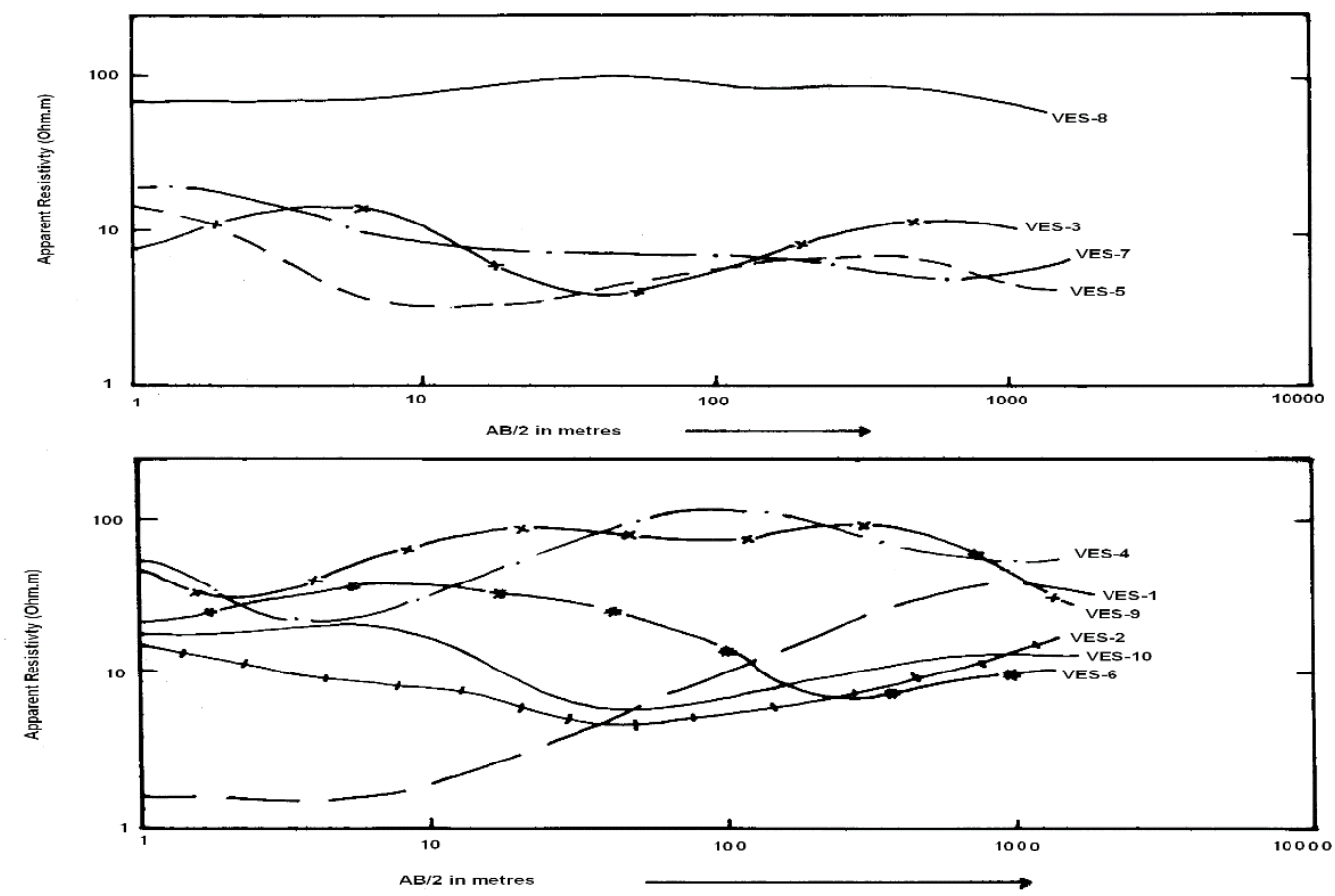

Figure 6: Schlumberger resistivity sounding in Sohagpur coal field area, district Shahdol, Madhya Pradesh.

The observed sounding curves are of KHA and HKA type, and in general, four or five subsurface formations are interpreted in the study area using "Orellana and Mooney" Master curves (Orellana and Mooney, 1966). The initial model parameters were used as input data to arrive at refined and accurate layer parameters using inversion techniques involving filter coefficients (Koefoed, 1976). A standard inverse modeling program 'Resist' is then used to get the model parameters. The details of soundings in the area are also given in Figure 7.

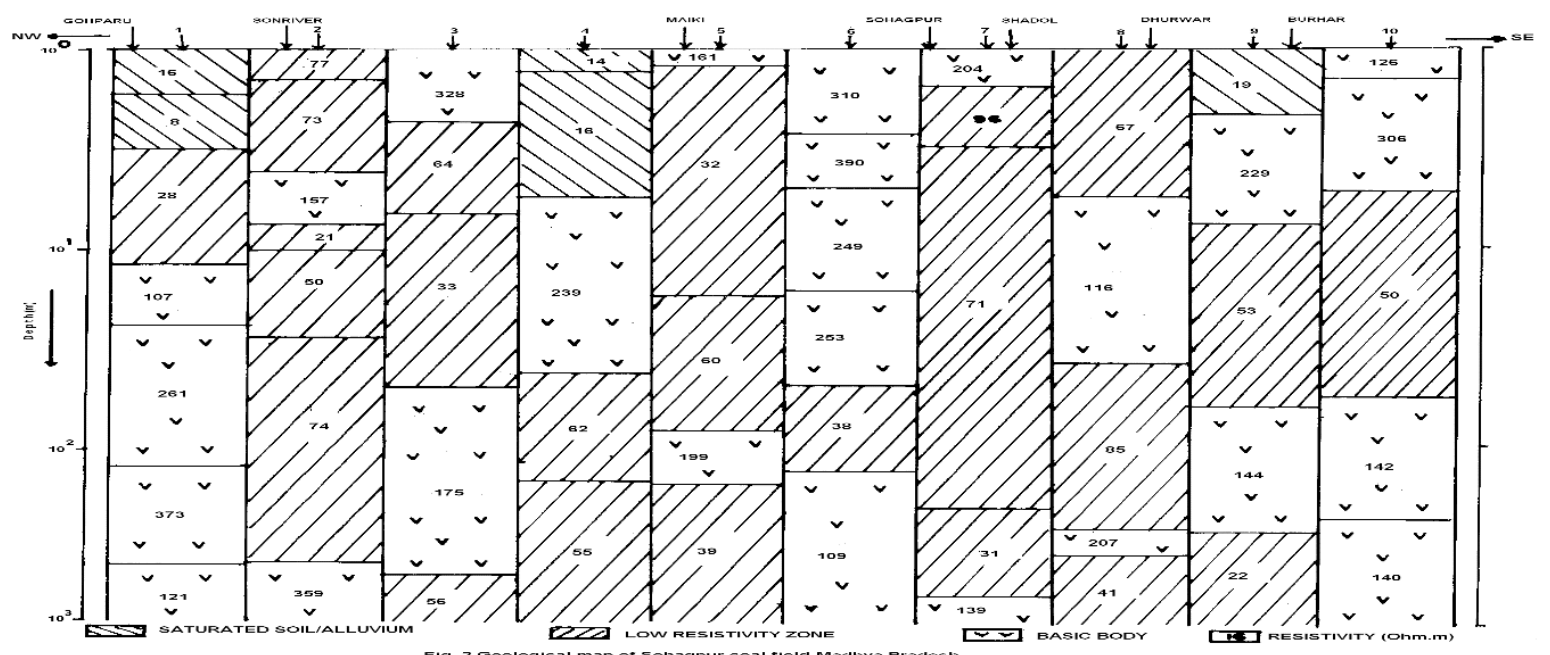

Figure 7: Interpreted vertical resistivity distribution along with lithology. 


\section{Resistivity Interpretation}

VES-1 The top layer having resistivity of $16 \mathrm{Ohm}-\mathrm{m}$ and thickness $1.7 \mathrm{~m}$ is followed by a layer having resistivity $8 \mathrm{Ohm}-\mathrm{m}$ and of thickness $1.5 \mathrm{~m}$. This is underlain by a layer having resistivity $28 \mathrm{Ohm}-\mathrm{m}$ and thickness $8.9 \mathrm{~m}$ and is followed by a layer having resistivity $107 \mathrm{Ohm}-\mathrm{m}$ and thickness $12.2 \mathrm{~m}$ which may possibly be the basic body at shallow depth. These are underlain by layers having resistivities $261 \mathrm{Ohm}-\mathrm{m}, 373 \mathrm{Ohm}-\mathrm{m}$ and $121 \mathrm{Ohm}-\mathrm{m}$ and of thicknesses $97.2 \mathrm{~m}$ and $257.1 \mathrm{~m}$ respectively. These are inferred as basic body.

VES-2 The top three layers having resistivities $167 \mathrm{Ohm}-\mathrm{m}, 77 \mathrm{Ohm}-\mathrm{m}$ and $73 \mathrm{Ohm}-\mathrm{m}$ and thicknesses $0.9 \mathrm{~m}, 0.5 \mathrm{~m}$ and $2.7 \mathrm{~m}$ are inferred which are followed by a layer having resistivity $157 \mathrm{Ohm}-\mathrm{m}$ and of thickness $3.2 \mathrm{~m}$. This may possibly be the basic body at shallow depth. These are underlain by three layers having resistivities $21 \mathrm{Ohm}-\mathrm{m}, 50 \mathrm{Ohm}-\mathrm{m}$ and $74 \mathrm{Ohm}-\mathrm{m}$ and of thicknesses $7 \mathrm{~m}, 26.7 \mathrm{~m}$ and $315.7 \mathrm{~m}$ respectively. Beyond a depth of $352.7 \mathrm{~m}$ a layer having resistivity 359 Ohm-m is inferred which may be the basic body at depth.

VES-3 The top layer having resistivity of $55 \mathrm{Ohm}-\mathrm{m}$ and thickness $0.6 \mathrm{~m}$ is followed by a layer having resistivity $328 \mathrm{Ohm}-\mathrm{m}$ and of thickness $1.7 \mathrm{~m}$ which may possibly be the basic body. This is underlain by a layer having resistivity $64 \mathrm{Ohm}-\mathrm{m}$ and thickness $4.3 \mathrm{~m}$ and is followed by a layer having resistivity $33 \mathrm{Ohm}-\mathrm{m}$ and thickness $42.7 \mathrm{~m}$. These are underlain by a layer having resistivity $175 \mathrm{Ohm}-\mathrm{m}$ and of thickness $386.3 \mathrm{~m}$ which may possibly be the basic body at depth. Beyond a depth of $435.6 \mathrm{~m}$ a layer having resistivity $56 \mathrm{Ohm}-\mathrm{m}$ is inferred.

VES-4 The top layer having resistivity of $64 \mathrm{Ohm}-\mathrm{m}$ and thickness $0.8 \mathrm{~m}$ is followed by a layer having resistivity $14 \mathrm{Ohm}-\mathrm{m}$ and of thickness $0.5 \mathrm{~m}$. This is underlain by a layer having resistivity 16 Ohm-m and thickness $4.1 \mathrm{~m}$ and is followed by a layer having resistivity $239 \mathrm{Ohm}-\mathrm{m}$ and thickness $37.1 \mathrm{~m}$ which may possibly be the basic body at shallow depth. These are underlain by layer having resistivity $62 \mathrm{Ohm}-\mathrm{m}$ and of thickness $102.1 \mathrm{~m}$. Beyond depth of $144.6 \mathrm{~m}$ a layer having resistivity $55 \mathrm{Ohm}-\mathrm{m}$ is inferred.

VES- 5 The top layer having resistivity $161 \mathrm{Ohm}-\mathrm{m}$ and thickness $1.2 \mathrm{~m}$ is inferred as dry surface layer. This is underlain by layers having resistivities $32 \mathrm{Ohm}-\mathrm{m}$ and $60 \mathrm{Ohm}-\mathrm{m}$ and of thicknesses $15.5 \mathrm{~m}$ and $63.3 \mathrm{~m}$ respectively. These are underlain by a layer having resistivity $199 \mathrm{Ohm}-\mathrm{m}$ and thickness $70.3 \mathrm{~m}$. This may possibly be the basic body at depth. Beyond a depth of $150.2 \mathrm{~m}$ a layer having resistivity $39 \mathrm{Ohm}-\mathrm{m}$ is inferred.

VES-6 The top layer having resistivity $178 \mathrm{Ohm}-\mathrm{m}$ and thickness $0.8 \mathrm{~m}$ is inferred which is underlain by four layers having resistivities $310 \mathrm{Ohm}-\mathrm{m}, 390 \mathrm{Ohm}-\mathrm{m}, 249 \mathrm{Ohm}-\mathrm{m}$ and $253 \mathrm{Ohm}-$ $\mathrm{m}$ and of thicknesses $1.7 \mathrm{~m}, 2.3 \mathrm{~m}, 11.5 \mathrm{~m}$ and $31.1 \mathrm{~m}$ respectively. The basic body is interpreted at a shallow depth of $0.8 \mathrm{~m}$ and of thickness $46.6 \mathrm{~m}$. These are underlain by a layer having resistivity $38 \mathrm{Ohm}-\mathrm{m}$ and of thickness $85.7 \mathrm{~m}$. Beyond a depth of $133.1 \mathrm{~m}$ a layer having resistivity 109 Ohm-m is inferred which may be the basic body at depth.

VES-7 The top layer having resistivity $208 \mathrm{Ohm}-\mathrm{m}$ and thickness $1.5 \mathrm{~m}$ is inferred as basic body which is underlain by layers having resistivities 96 Ohm-m, 71 Ohm-m and 31 Ohm-m and of 
thicknesses $1.5 \mathrm{~m}, 195.3 \mathrm{~m}$ and $349.3 \mathrm{~m}$ respectively. Beyond a depth of $547.5 \mathrm{~m}$ a layer having resistivity 139 Ohm-m is inferred which may possibly be the basic body at depth.

VES-8 The top two layers having resistivities $72 \mathrm{Ohm}-\mathrm{m}$ and $67 \mathrm{Ohm}-\mathrm{m}$ and of thicknesses $0.9 \mathrm{~m}$ and $4.5 \mathrm{~m}$ respectively are inferred. These are underlain by a layer having resistivity $116 \mathrm{Ohm}-\mathrm{m}$ and of thickness $30.8 \mathrm{~m}$ which may be the basic body at shallow depth. This is again underlain by a layer having resistivity $85 \mathrm{Ohm}-\mathrm{m}$ and of thickness $218.2 \mathrm{~m}$ which is followed by a layer having resistivity $207 \mathrm{Ohm}-\mathrm{m}$ and thickness $87 \mathrm{~m}$. This may be the basic body at depth. Beyond a depth of $341.4 \mathrm{~m}$ a layer having resistivity $41 \mathrm{Ohm}-\mathrm{m}$ is inferred.

VES-9 The top two layers having resistivities $86 \mathrm{Ohm}-\mathrm{m}$ and $19 \mathrm{Ohm}-\mathrm{m}$ with thicknesses $0.5 \mathrm{~m}$ and $1.6 \mathrm{~m}$ respectively are interpreted. These are underlain by a layer having resistivity $229 \mathrm{Ohm}-$ $\mathrm{m}$ and thickness $5.4 \mathrm{~m}$, possibly may be the basic body at shallow depth which in turn underlain by a layer of resistivity 53 Ohm-m and of thickness $53.8 \mathrm{~m}$. This is underlain by a layer having resistivity 144 Ohm-m and thickness $201 \mathrm{~m}$ which may possibly be the basic body at depth. Beyond the depth of $262.4 \mathrm{~m}$ a layer having resistivity 22 Ohm-m is inferred.

VES-10 The top three layers having resistivities $188 \mathrm{Ohm}-\mathrm{m}, 126 \mathrm{Ohm}-\mathrm{m}$ and $306 \mathrm{Ohm}-\mathrm{m}$ and thicknesses $0.7 \mathrm{~m}, 0.7 \mathrm{~m}$ and $3.6 \mathrm{~m}$ respectively are inferred as basic body which is followed by a layer having resistivity $50 \mathrm{Ohm}-\mathrm{m}$ and thickness $50.1 \mathrm{~m}$. It is underlain by a layer having resistivity 142 Ohm-m and thickness $265.5 \mathrm{~m}$ which in turn underlain by a layer having resistivity $140 \mathrm{Ohm}-$ $\mathrm{m}$. These are the basic body inferred at depth.

\section{Geo-Electric Section}

The interpreted vertical resistivity distribution and inferred lithology are shown for easy comprehension in Figure 7. The higher resistivity basic body is inferred from surface to a depth of $547.5 \mathrm{~m}$. The basic body is characterized by resistivity ranging 107-390 Ohm-m and thickness varies from 0.7-386.3 m. At greater depths, basic body inhomogeneity has also been interpreted. High resistivity basement could not be picked up by resistivity survey.

\section{Conclusions}

The systematic magnetic survey carried out along N-S traverse in Sohagpur coal field area has brought prominent magnetic anomaly zones which indicate excellent correlation with surface geology. The area under investigation is dominantly occupied by Raniganj formation associated with intrusion of basic bodies which are well reflected by magnetic data. Lateral disposition of basic body is well depicted along magnetic anomaly zones. Three sets of structural discontinuity are interpreted in the magnetic (VF) contour map which may represent the change in the disposition of basic body in the area. As the Gondwana formation is of generally non-magnetic in character, the contour pattern in the area is mainly governed by basic intrusive. Magnetic anomalies of low amplitude over Raniganj formation reflect the disposition of Archaean basement in the area. 2D magnetic modeling and spectral analysis of vertical magnetic field in the central part of the area has brought out the thickness of the Gondwana sediments that is underlain by basement rock. 
The vertical electrical sounding observed in the area at specified location has brought out lithological variations in term of resistivity distribution. The high resistivity layer (107-390 Ohm$\mathrm{m})$ may possibly indicate the geometry of basic bodies right from the surface to depth of $547.5 \mathrm{~m}$. The basement depth could not be picked up.

\section{Acknowledgements}

The Director General of the Geological Survey of India is gratefully acknowledged for his kind permission to publish this paper.

\section{List of Figures}

Figure 1 Lay out map showing magnetic traverses and resistivity sounding locations in Sohagpur coal field, district Shahdol, Madhya Pradesh.

Figure 2 Geological map of Sohagpur coal field, Madhya Pradesh.

Figure 3 Magnetic (VF) anomaly along north-south traverses with geology.

Figure 4 Magnetic (VF) contour map of Sohagpur coal field, district Shahdol, Madhya Pradesh.

Figure 5 Magnetic (VF) profile along AO-OB. Lower boundary of Gondwana sediments inferred from $2 \mathrm{D}$ modeling and spectral analysis are also shown.

Figure 6 Schlumberger resistivity sounding in Sohagpur coal field area, district Shahdol, Madhya Pradesh.

Figure 7 Interpreted vertical resistivity distribution along with lithology.

\section{References}

[1] K Chakravorty, B.N.P. Agarwal, and L.K. Das. (1998). "Preliminary idea of crustal structure from analysis of gravity data in Central India". Indian Minerals, 52 (1 \& 2), 57-66.

[2] D.P. Ghosh, S. Adhikari, S.P. Roy, and S. Sinha. (1996). "Report on development and potential of high rank coal in Sohagpur coalfield, Shahdol district, MP”. Unpub. Rep. GSI.

[3] M.V. Joga Rao, K. Padmanabhan, and K.S. Benhur. (1984). "Report on the regional gravity, magnetic, deep electrical resistivity and refraction seismic surveys to study the basement configurations and associated structural features in aid to coal explorations in Sohagpur coal areas, Shahdol district, Mp". GSI unpub. Rep.

[4] G. Kunetz. (1966). "Principles of direct current resistivity prospecting". Gebruder Borntraeger, Berlin, pp. 106.

[5] E. Orellana, and H.M. Mooney. (1966). "Master tables and curves for vertical electrical sounding over layered media". Intercientia, Madrid, Spain.

[6] O. Koefoed. (1976). "Progress in the direct interpretation of resistivity sounding and algorithm". Geophysical prospecting, 24, 233-240.

[7] A.I. Olayinka, and A. Weller. (1997). "The inversion of geoelectrical data for hydrological application in crystalline basement areas of Nigeria". Jour. Applied Geophysics, 37, 103-115.

[8] N.J. Raju, and T.V.K. Reddy. (1998). "Fracture pattern and electrical resistivity studies for groundwater exploration". Environ. Geology, 34, 241-259.

[9] B.P.A. Vander Velpen. (1988). "A computer processing package for DC resistivity interpretation for a IBM compatibles". ITC Jour. 4, the Netharlands.

[10] G.S. Yadav, and H. Abolfazli. (1998). "Geoelectrical soundings and their relationship to hydraulic parameters in semiarid regions of Jalore, North Western India". Jour. Applied Geophysics, 39, 3551. 
[11] O.M. Ilkisik, A. Gurer, T. Tokgoz, and C. Kaya. (1997). Geo-electromagnetic and geothermic investigations in the Ihlara valley geothermal field. Jour. Volcanol. Geotherm. Res., 4, 297-308.

[12] R.K. Majumdar. (1999). "Groundwater conditions in Port Blair region of south Andaman areas". Proc. Symposium on Disaster Management, Calcutta, 130-137.

[13] R.K. Majumdar, N. Majumdar, A.L. Mukherjee. (2000a). "Geoelectric studies for hydrological characterization of Bakreswar geothermal area". Proc. Symposium on Application of Geophysics to Engineering and Environmental Problems. Virginia, USA, 1009-1017.

[14] R.K. Majumdar, N. Majumdar, and A.L. Mukherjee. (2000b). Geoelectric investigation in Bakreswar geothermal area, West Bengal, India. Jour. Applied Geophysics, 45, 187-202.

[15] R.K. Majumdar, A.L. Mukherjee, N.G. Roy, K. Sarkar, and S. Das. (2002). "Groundwater studies on South Sagar Island region, South 24-Parganas, West Bengal. Analysis and practice in water resources engineering for disaster mitigation”. Indian Association of Hydrologist, West Bengal Regional Centre, 1, 175-183.

[16] R.K. Majumdar, and S. Pal. (2005). "Geoelectric and borehole lithology studies for ground water investigation in alluvial aquifers of Munger district, Bihar". Jour. Geol. Soc. India, 66 (4), 463-474.

[17] R.K. Majumdar, A. Ghosh, and D. Das. (2006). "Geoelectric and geochemical studies for hydrological characterization of southern part of Sagar Island, south 24 Parganas, West Bengal, India". Jour. Geophys., xxvii (4), 109-118.

[18] F.A. Monteiro Santos, A. Dupis, Andrade, A.R. Afonso, and L.A. Mendes Victor. (1997). "1-D joint inversion of AMT and resistivity data acquired over a graben". Jour. Applied Geophysics, 38, 115-129.

[19] I.V.R. Murthy, and D.C. Mishra. (1989). "Interpretation of gravity and magnetic anomalies in space and frequency domain". Assoc. Explor. Geophys. Hyderabad, 77-113.

[20] D.C. Naskar, K. Choudhury, K.K. Roy, O.P. Singh, and R.K. Majumdar. (2002). "Geophysical approach for delineation of shallow crustal structure along Borgaon-Sanwer transect, Madhya Pradesh". Jour. Geol. Soc. India, 60, 173-181.

[21] D.C. Naskar. (2005). "Structural studies of crust and upper mantle structures in parts of Madhya Pradesh and Maharashtra, Central India". Ph. D thesis, Jadavpur University, p 150.

[22] D.C. Naskar, L.K. Das, K.K. Roy, and O.P. Singh. (2008). "Structural studies of crust and upper mantle in parts of Madhya Pradesh, Central India". Spl. Publ. Geol. Surv. India, 91, 211-228.

[23] D.C. Naskar, and L.K. Das. (2009). "Resistivity survey across the Narmada-Son lineament and along the Sanwer-Borgaon traverse, Madhya Pradesh, Central India”. Bollettino di Geofisica Teorica ed Applicata, 50 (4), 305-318.

[24] B.N. Rao, and P. Ramakrishna. (1994). "Magpros- An interactive Fortran 77 PC program for magnetic data processing". Computers and Geosciences, 20 (5), 681-717.

[25] A. Spector, and F.S. Grant. (1970). "Statistical models for interpreting aeromagnetic data". Geophysics, 35 (2), 293-302.

[26] M. Stewart, M. Layton, and T. Lizanec. (1983). "Application of resistivity surveys to regional hydrologic reconnaissance". Groundwater, 21 (1), 42-48.

[27] N. Venkatappyya, G.P. Deshmukh, and A.K. Srivastava. (1968). "Report on the investigation for coal in parts of Sohagpur coalfield, Shahdol district, MP”. Unpub. Rep. GSI.

*Corresponding author.

E-mail address: dcnaskar @yahoo.com 